\title{
DIGITALISASI GAMELAN DAN PENYEBARAN NILAI ADILUHUNG BUDAYA ISLAM
}

\author{
Warto \\ STAIN Purwokerto \\ Jl. A. Yani 40 A (+62-281) 635624 Purwokerto 53126 \\ E-mail:warto@stainpurwokerto.ac.id \\ HP. +62-85869433585
}

Abstract: This paper reveals the development of gamelan in digital form which is done in many different forms, ranging from stand-alone e-gamelan, Internet-based e-gamelan, and e-gamelan in mobile devices. Gamelan musical instruments has been a Javanese cultural identity since time immemorial. Gamelan Javanese cultural identity that has, in fact full of Islamic values. Therefore, with the digitization gamelan, this is tantamount to doing good and as a means to draw closer to Allah SWT.

Abstrak: Tulisan ini mengungkap perkembangan gamelan dalam bentuk digital yang dilakukan dalam berbagai wujud mulai dari e-gamelan stand alone, e-gamelan berbasis internet, dan e-gamelan di perangkat mobile. Alat musik gamelan telah menjadi identitas budaya Jawa sejak zaman dahulu kala. Gamelan yang memiliki identitas budaya Jawa penuh dengan nilai-nilai Islami. Oleh karena itu, dengan adanya digitalisasi gamelan, hal ini sama saja dengan melakukan kebaikan dan sebagai sarana mendekatkan diri kepada Allah SWT.

Kata kunci: gamelan, e-gamelan, digital, Islam, musik.

\section{A. Pendahuluan}

Gamelan menjadi salah satu alat musik tradisional Indonesia yang telah mendunia. Gamelan dapat disejajarkan dengan alat musik etnik dari berbagai negara di antaranya Djembe Drumming (Afrika), Capoeira Dancing (Brazil), Samba (Brazil), Taiko Drumming (Jepang), atau Didgeridoo (Australia) (Johnson, 2008: 55). Selain itu, alat musik gamelan juga dipelajari di berbagai universitas seperti di Amerika, Eropa, Jepang, Australia, New Zealand, Canada, Jerman, Perancis, Belgia, hingga Israel dan belahan dunia lain. Di Belanda 
pernah diselenggarakan Konferensi Gamelan Internasional pada tahun 2007 yang membahas perkembangan musik gamelan baik di Indonesia maupun di seluruh dunia (Johnson, 2008: 55). Dengan demikian, sudah tidak dipungkiri lagi bahwa warisan kebudayaan kita telah benar-benar diakui di mata dunia.

Alat musik gamelan dipelajari di berbagai perguruan tinggi dunia dengan mendatangkan maestro gamelan dari Indonesia. Tidak sedikit mahasiswa yang mempelajari gamelan dan antusias mengikuti latihan-latihan yang diberikan oleh pengajar. Dalam waktu-waktu tertentu juga dilakukan performing gamelan kepada khalayak luas dan terlihat ant usiasme masyarakat luar negeri menyaksikan penampilan musik gamelan. Beberapa dari mereka -masyarakat umumbahkan tertarik untuk belajar cara menabuh gamelan.

Begitu ant usiasnya warga negara asing terhadap musik gamelan hingga muncul portal gamelan internasional yang beralamat di http://www.gamelan. org. Portal ini bernaung di bawah institusi American Gamelan Institut (AGI) yang didirikan sejak 1981, yang bertujuan untuk mendukung perkembangan musik gamelan di seluruh dunia. Bentuk dukungan tersebut diwujudkan dalam bentuk publikasi, merekam, mendistribusikan, dan menyediakan informasi yang berkaitan dengan alat musik gamelan (AGI, 1981, web). Informasi yang diberikan di antaranya buku dan artikel-artikel ilmiah yang membahas tentang gamelan, rekaman musik gamelan yang bisa diunduh. Selain itu, juga berisi direktori grup gamelan internasional di seluruh dunia, perpustakaan yang berisi referensi untuk belajar gamelan serta informasi lainnya.

Gamelan, sebenarnya, tidak hanya berisikan identitas Jawa, tetapi juga ada ruh Islami yang melekat di dalamnya. Ada nafas-nafas Islam yang berdialektika di dalam gamelan (Chodjim, 2003: 11). Sunan Kalijaga menggunakan gamelan sebagai sarana dakwah di Jawa. Hal inilah yang pat ut untuk dicermati bahwa gamelan tidak hanya berisi keindahan rasa, tetapi juga ada nilai luhur dan sarana untuk mendekatkan diri pada Allah SWT.

Tulisan ini bermaksud mengungkap peran teknologi dalam melestarikan budaya lokal Islam yang memiliki nilai luhur. Hal ini sekaligus menegaskan bahwa Islam sebenarnya lent ur dengan keberadaan dari teknologi dan perubahan zaman. Dalam hal ini, Jawa (bagian dari Timur) menjadi entitas yang dipelajari oleh orang-orang dari Barat.

\section{B. Gamelan dan Spiritualitas Islam JaWA}

Gamelan secara harfiah memiliki arti perangkat alat musik Jawa (termasuk juga Sunda dan Bali) yang terdiri atas saron, bonang, rebab, gendang, dan gong. Gamelan sendiri berasal dari bahasa Jawa "gamel” yang berarti memukul, diikuti 
akhiran "an" sehingga menjadikannya kata benda (Chodjim, 2003: 7). Gamelan diperkirakan lahir pada masa kerajaan Hindu-Budha mendominasi Indonesia. Menurut mitologi Jawa, gamelan diciptakan oleh Sang Hyang Guru pada era Saka. Beliau adalah dewa yang menguasai seluruh tanah Jawa, dengan istana yang berada di Gunung Mahendra di daerah Medang Kamulan. Sang Hyang Guru pertama menciptakan gong untuk memanggil para dewa. Untuk pesan yang lebih spesifik kemudian menciptakan dua gong, lalu akhirnya terbentuk set gamelan (Muhaya, 2003: 5).

Dalam Islam, derajat tertinggi dalam beragama adalah jika telah mencapai derajat kedekatan yang paling dekat dengan Allah SWT. Tandanya adalah merasa bahwa segala tindakan kita terlihat oleh Allah sehingga merasa malu jika melakukan hal-hal yang dilarang oleh-Nya. Untuk mencapai kedekatan tersebut dapat ditempuh dengan berbagai cara dan salah satunya adalah melalui musik. Namun, di kalangan ulama Islam sendiri, terjadi perbedaan pendapat mengenai musik. Satu kelompok menghalalkan dan membolehkan mendengarkan musik, karena dengan musik dapat mengantarkan jiwa seseorang dalam suasana hening dan dapat mencapai kedekatan dengan Allah. Adapun kelompok yang lain mengharamkan musik dengan alasan memiliki dampak negatif bagi pendengarnya. Orang yang mendengarkan musik akan menjadi lalai dari mengingat Allah SWT karena terlalu asyik mendengarkan musik. Selain itu juga dapat mendorong orang melakukan gerakan-gerakan yang kurang pantas dan juga menghambat kewajiban karena terlalu hanyut dalam alunan musik.

Menurut Muhaya, asal muasal musik terdiri dari dua mazhab, yaitu mazhab revelationism dan naturalism. Mazhab revelationism memiliki pandangan bahwa musik sebagai seni suara dan sekaligus sebagai sesuatu yang memiliki dimensi magis, ritual, dan memiliki pertalian erat dengan agama. Oleh karena itu, musik dapat berfungsi sebagai media untuk meningkatkan kualitas keagamaan dan Oleh karena itu, masuk — dan alat musik—sebagai media yang sakral dan disakralkan. Adapun menurut mazhab naturalism, musik adalah bagian dari budaya manusia karena tumbuh dan berkembang bersama dengan pertumbuhan dan perkembangan manusia. Menurut penulis, musik adalah sesuatu yang netral, karena hanya sebagai media. Dalam konteks ini, musik akan tergantung pada bagaimana orang memandangnya, menyifatinya, dan menggunakannya. Jika digunakan untuk hal-hal yang tidak baik, misalnya untuk mengiringi syair yang tidak baik, maka musik menjadi tidak baik, namun jika orang menggunakannya untuk mengiringi syair lagu untuk selalu mengingat Yang Maha Pencipta maka musik akan menjadi hal yang diperbolehkan. Kedua mazhab tersebut masingmasing mengandung kebenaran dan juga sekaligus mengandung kontroversi. 
Imam al-Ghazāii, seorang ulama besar yang juga seorang Sufi dalam kitab al-Samā' menjelaskan mengenai faedah mendengarkan musik seperti ditulis oleh Muhaya di antaranya: dapat menghilangkan sampah batin, menguatkan hati, melepaskan seorang Sufi dari berbagai urusan yang bersifat lahir, dan dapat menjadikan jiwa-jiwa bahagia. Untuk menguatkan pendapatnya, Imam alGhazali menukil ayat al-Qur'an yang menjadi dalil dihalalkannya mendengarkan musik yaitu Q.S.8:23, Q.S.39:17-18, dan Q.S.31:16. Selain itu juga terdapat beberapa hadis yang membolehkannya mendengarkan musik dan hukumnya adalah mubah (Muhaya, 2003: 5).

Dalil berikutnya adalah yang bersumber dari hadis Rasulullah SAW, terdapat beberapa hadis yang dipertentangkan oleh para ulama terkait pandangannya mengenai keberadaan musik. Salah satunya adalah hadis yang diriwayatkan oleh Ali bin Abi Thalib bahwa Rasulullah bersabda: "Apabila umatku telah mengerjakan limabelas perkara, maka telah halal bagi mereka bala'. Dan Beliau SAW menghitung salah satu di antaranya adalah umatku memakai alat-alat musik". (H.R. al-Tirmizy). Para ulama kebanyakan menvonis hadis ini adalah lemah. Bahkan perawinya sendiri yaitu at-Tirmizy menyebutkan dalam Sunan at-Tirmizy bahwa hadis tersebut tidak sahih. Jika dari perawinya sendiri telah mengatakan demikian, maka sangat tidak masuk akal jika hadis tersebut masih dijadikan hujjah untuk mengharamkan musik. Selain itu juga masih terdapat banyak hadis-hadis lain yang menjadi kontroversi di kalangan ulama, namun jika pelajari lebih dalam lagi memang tidak ada hadis yang secara langsung mengharamkan musik. Kalaupun ada, ternyata hadis tersebut lemah dan tidak bisa dijadikan landasan. Oleh karena itu, keberadaan musik adalah mubah.

Dikatakan mubah karena tidak ada dalil yang secara langsung dengan jelas mengharamkan musik. Kalaupun ada, dalil tersebut sanadnya terput us sehingga tidak sahih. Jika dikembalikan pada hukum asal sesuatu bahwa jika tidak ada dalil yang mengharamkan sesuatu secara langsung, maka sesuatu itu hukumnya mubah. Artikel ini tidak akan melakukan konfrontasi secara langsung dalil hadis-hadis yang dipertentangkan oleh para ulama dalam memandang keberadaan musik. Akan tetapi, jika kita kembalikan kepada hukum asal di atas, maka menurut hemat penulis, musik adalah sesuatu yang mubah. Dengan pendapat di atas, maka gamelan sebagai salah satu instrumen musik keberadaannya dalam Islam adalah mubah alias diperbolehkan (Muhaya, 2003: 5).

Sebagai warisan kebudayaan adiluhung Jawa, gamelan yang telah mengakar di tanah Jawa juga memiliki nilai spiritual yang tinggi bagi masyarakat Jawa. Walton (2007) mengungkapkan bahwa menurut pemain musik 
gamelan dapat meningkatkan kualitas spiritual. Hanya jiwa yang bersih yang dapat menikmati indahnya alunan musik gamelan, dan jika semakin dinikmati maka akan semakin membuat kecanduan. Masih menurut Walton, "rasa" adalah bagian integral tradisi mistik masyarakat Jawa yaitu tradisi tantra Hindu dan Budha Mahayana di satu sisi serta sufisme Islam di sisi lain. Tak dipungkiri bahwa masyarakat Jawa dalam sejarah budayanya sangat dipengaruhi oleh budaya Hindu, Budha, dan Islam. Seni musik gamelan juga tak luput dari pengaruh tersebut. Terutama dalam tradisi Hindu, musik menjadi instrumen untuk mendekatkan diri kepada yang Maha Kuasa. Musik dijadikan sarana olah "rasa", mengasah naluri jiwa spiritual seseorang agar memiliki perasaan yang semakin halus. Masyarakat Jawa berkeyakinan dengan perasaan yang halus tersebut maka akan menjadikan jiwa makin sensitif yang efeknya adalah dapat merasakan kehadiran Tuhan.

Selain Hindu dan Budha, agama Islam pada saat awal perkembangannya di masyarakat Jawa juga menggunakan gamelan sebagai salah satu alat untuk berdakwah. Sunan Kalijaga yang mengawali penggunaan perangkat gamelan sebagai media untuk syiar Islam. Dengan media gamelan tersebut, banyak masyarakat Jawa yang akhirnya masuk agama Islam dengan sukarela. Salah satu puncak dari implementasi gamelan sebagai media syiar Islam adalah acara Grebeg Mulud yang diiringi dengan musik gamelan. Acara tersebut masih bisa kita saksikan hingga kini yang populer disebut dengan Sekaten. Gamelan sebagai budaya yang sudah mengakar di masyarakat Jawa dijadikan sebagai media pengenalan agama Islam. Lagu-lagu pemujaan dewa digubah liriknya menjadi bernafaskan Islam oleh Sunan Kalijaga. Kata "gamelan" sendiri juga ditafsirkan secara filosofis sebagai "Gusti Allah Maringi Emut Lakonono Ajaran Nabi". Dengan gamelan mengajak masyarakat Jawa untuk mengingat perintah Allah dalam menjalankan sunah Nabi, yaitu nabi Muhammad SAW.

Sekaten adalah peringatan kelahiran Nabi Muhammad SAW. Pada awal perkembangannya, gamelan digunakan untuk mengundang warga agar ant usias datang ke serambi masjid mendengarkan alunan musik gamelan. Karena memang literasi gamelan yang sudah mendarah daging di masyarakat Jawa, tidak sungkan bagi mereka untuk datang ke masjid. Di sela-sela alunan musik gamelan dan diakhir pertunjukan, disisipkan dakwah Islam. Di sinilah fungsi gamelan pada saat itu begitu penting dalam penyebaran agama Islam di Jawa. Tidak hanya Sunan Kalijaga saja yang menggunakan gamelan sebagai media syiar Islam, Walisongo yang lain juga menggunakannya untuk syiar Islam di tanah Jawa di antaranya Sunan Bonang dan Sunan Giri. 
Namun, gamelan yang hanya digunakan sebagai alat syiar Islam disakralkan oleh sebagian masyarakat Kejawen. Yang belum bisa berubah hingga saat ini adalah bahwa gamelan adalah alat musik yang disakralkan oleh kalangan Islam Abangan. Hal ini terlihat dari proses jamas yang dilakukan secara rutin untuk mencuci gamelan dengan air kembang dan berbagai sesaji yang melengkapinya. Seharusnya, hal ini bisa dibersihkan oleh pendakwah Islam masa kini dengan menghilangkan pensakralan terhadap perangkat gamelan. Pensakralan ini adalah buah dari orang yang mendengarkan begitu nikmatnya alunan musik gamelan sehingga mengantarkannya sampai ke titik ketuhanan dalam batin mereka.

Musik gamelan yang memiliki makna filosofis dan sufistik menjadikannya perlu dan harus dilestarikan dan diperdengarkan kepada generasi mendatang. Lebih luas lagi, juga generasi saat ini dan mendatang dapat memainkan musik gamelan dan meresapi makna yang terkandung di dalamnya. Untuk keperluan tersebut, maka digitalisasi musik gamelan sebagai salah satu upaya untuk melestarikan alat musik tradisional Jawa patut diapresiasi dan diberi dukungan sepenuhnya dari semua kalangan. Pemerintah juga memiliki peran dalam misi ini, salah satunya dengan cara memberikan paten terhadap hasil karya digitalisasi alat musik gamelan sehingga punya kekuatan hukum jika di lain hari hal yang sama dilakukan oleh peneliti-peneliti dari luar negeri.

\section{Digitalisasi Gamelan: Penyebaran Spiritual Islam Jawa}

Digital berasal dari Bahasa Yunani yaitu digitus (Anonim, 2012), yang artinya jari-jemari. Menurut Kamus Besar Bahasa Indonesia, digital berhubungan dengan angka-angka untuk sistem perhitungan tertentu (KBBI, 2000:264). Makna kata digital adalah baris bilangan yang terdiri dari 0 dan 1 yang dalam ilmu komputer disebut dengan bilangan biner. Bilangan tersebut yang mendasari cara kerja komputer. Mesin komputer hanya mengenal sinyal listrik arus rendah positif yang dinotasikan dengan angka 1 (satu) dan sinyal negatif yang dinotasikan dengan angka 0 (nol). Instruksi-instruksi yang diberikan oleh pengguna komputer dari perangkat input dikirim ke central processing unit dalam bentuk sinyal digital untuk selanjutnya dilakukan pemrosesan. Hasil pemrosesan tersebut selanjutnya diberikan kepada pengguna melalui perangkat output yang sesuai dengan instruksi.

Perkembangan teknologi digital berimbas terhadap perkembangan musik. Sebelum era digital, untuk memainkan musik diperlukan alat musik yang ingin dimainkan. Misalnya ingin bermain gitar, maka diperlukan gitar yang hadir secara fisik yang dapat dipegang dan dimainkan. Seperti halnya gamelan juga 
jika ingin memainkannya maka harus menggunakan seperangkat gamelan yang harganya tidaklah murah.

Pada awalnya, perkembangan musik digital sebatas pada bagaimana alat musik yang dimainkan suaranya dapat direkam ke dalam media simpan tertentu sehingga bisa dinikmati tanpa kehadiran alat musik secara fisik. Pertunjukan wayang kulit dan wayang orang yang musik pengiringnya adalah gamelan, dapat direkam dan dikemas dalam media simpan digital seperti CD dan DVD. Pada era selanjutnya, muncul ide untuk mengemas alat musik dalam bentuk digital, sehingga bisa bermain alat musik dengan media komputer. Perkembangan ini juga berimbas pada alat musik gamelan, yakni banyak para peneliti yang mencoba untuk mengemas alat musik gamelan dalam bentuk digital.

Dengan begitu, digitalisasi gamelan terdapat dua paradigma, pertama adalah digitalisasi terhadap musik sebagai produk digital, kedua adalah digitalisasi gamelan terhadap alat musik dari bentuk fisik ke bentuk digital. Dari kedua paradigma tersebut, artikel ini lebih berfokus pada paradigma kedua, yaitu bagaimana seperangkat alat musik gamelan dikemas dan dimainkan secara digital.

\section{Digitalisasi Budaya Indonesia}

Sebenarnya tidak dapat juga sepenuhnya menyalahkan generasi muda yang semakin meninggalkan musik gamelan. Karena perubahan kebudayaan adalah keniscayaan, mau tidak mau pasti akan terjadi. Namun perubahan yang dimaksud tidak mengubah esensi budaya yang telah ada, namun lebih kepada kemasan dalam bentuk inovasi teknologi untuk mengemas sebuah kebudayaan. Salah satu kebudayaan yang mengalami perubahan dalam hal kemasan adalah batik. Penelitian yang dilakukan oleh I Putu Wandra Adnyana untuk mengembangkan aplikasi pembuatan pola motif batik menggunakan pengolahan citra digital (Adnyana, 2012: 249-262). Dari penelitian melalui ujicoba yang dilakukannya, Andyana menghasilkan sebuah perangkat lunak yang dapat membantu dalam pembuatan motif batik. Dengan perangkat lunak tersebut, pembuat batik dapat dengan mudah membuat motif baru secara cepat dan layak dipasarkan.

Antusiasme dari luar negeri terhadap gamelan tidak hanya pada keinginan untuk belajar memainkan alat musik tersebut, namun juga meneliti dengan melakukan analisis spektogram terhadap alat musik gamelan yang dilakukan oleh Mohn dan kawan-kawan dari Cornell University U.K. (Mohn, Chivers, Hatch, Howard, \& Sachse, 1998: 326-334). Penelitian dilakukan untuk mengetahui spektogram (spektrum suara) perbedaan bunyi antara kenong dan bonang melalui sinyal digital. Penelitian ini dilakukan karena bentuk dan bunyi kedua 
alat musik tersebut memiliki kemiripan, sehingga dibutuhkan penelitian khusus untuk dapat membedakannya secara digital. Penelitian ini selanjutnya menjadi acuan dalam menentukan spektrum suara kenong dan bonang saat melakukan digitalisasi gamelan.

Latif juga melakukan penelitian mengenai analisis dan identifikasi spektrum suara bonang. Dalam penelitian ini digunakan algoritma Back Propagation Artificial Neural Network. Metode ekstraksi yang digunakan adalah Fast Fourier Transform dengan metodologi selengkapnya diawali dari proses perekaman suara, segmentasi, fast fourier transform yang berfungsi untuk mengubah sinyal suara dari domain waktu ke domain frekuensi, Power Spectral Density adalah transformasi fourier dengan fungsi autocorrelation yang mendeskripsikan kekuatan sinyal yang telah terdistribusi secara frekuensi, Artificial Neural Network merupakan proses yang terdiri dari layer input, hidden layer, dan layer output, hingga mendapatkan hasil yang diinginkan. Hasil dari penelitian ini adalah mengetahui spektrum suara yang dikeluarkan oleh bonang, dengan dasar spektrum ini maka bisa diciptakan bonang digital yang memiliki suara sangat mirip dengan suara bonang asli.

\section{E. Digitalisasi Gamelan di Komputer}

Joko Triyono, Guru kesenian SMAN Prembun Kabupaten Kebumen menciptakan gamelan digital menggunakan aplikasi Adobe Flash. Pada awalnya, ia prihatin dengan keadaan gamelan di sekolah yang telah rapuh dimakan usia, sedangkan untuk pengadaan perangkat gamelan baru membutuhkan dana hingga puluhan juta rupiah. Berawal dari pelatihan media pembelajaran yang diikutinya, maka terpikir untuk mengemas alat musik gamelan secara virtual. Setelah gamelan dikemas secara virtual, siswa menjadi lebih ant usias mengikuti pelajaran kesenian, utamanya belajar gamelan.

Inovasi Joko Triyono tersebut bertujuan menanamkan dan mengembangkan rasa cinta generasi muda pada budaya gamelan. Selain itu juga memberi solusi kepada sekolah yang belum mempunyai peralatan gamelan. Karya yang dirintis sejak tahun 2005 ini sampai saat ini masih terus disempurnakan. Dari hasil karyanya tersebut, Joko Triyono mendapatkan penghargaan dari Direktorat HAKI dan dari MURI (dalam Suara Merdeka, 2011). Untuk memainkan gamelan ini, tiap siswa memainkan musik dengan menekan tombol mouse di komputer. Pada layar monitor tiap laptop, terlihat bentuk alat musik yang mereka mainkan. Setiap laptop digunakan untuk memainkan satu jenis gamelan. Gamelan virtual karya Joko Triyono ini juga dapat dinikmati di internet dengan alamat www. virtualgamelan.com. 
Untuk mendapatkan suara digital yang standar sesuai dengan suara gamelan asli, Suprapto dan kawan-kawan melakukan penelitian mengenai hal tersebut. Suprapto (Suprapto, 2012: 26-31) mengusulkan membuat model instrumen gamelan untuk mengatasi masalah pembangunan gamelan di industri gong dengan membuat dua jenis model frekuensi balungan. Model pertama adalah menggunakan nilai rata-rata, sedangkan model kedua menggunakan nilai rata-rata di daerah yang paling padat. Tingkat kesalahan ant ara model yang diusulkan dengan kenyataan untuk model pertama sebesar $0,0222 \%$, sedangkan model kedua menunjukkan tingkat kesalahan sebesar 0,0410\%. Jika dilihat dari hasil penelitian tersebut, maka model yang diusulkan dapat digunakan untuk membangun gamelan digital dengan hasil yang tidak terlalu berbeda dengan gamelan sebenarnya.

Digitalisasi gamelan juga dilakukan oleh tim peneliti dan mahasiswa Universitas Dian Nuswantoro Semarang. Proyek digitalisasi yang didanai oleh Dirjen Dikti pada tahun 2009 ini dilakukan untuk seluruh gamelan yang terdiri dari Bonang Barung, Bonang Penerus, Kenong, Saron Penerus, Saron Barung, Demung, Slenthem, Kethuk Kempyang, Kendhang, dan Gong (Catur, 2010). Saat ini e-gamelan tersebut dapat dimainkan secara online, baik single user maupun multi user di alamat www.egamelanku.com. Karena bisa diakses secara online, maka siapa saja dan kapan saja dapat belajar memainkan alat musik gamelan tanpa harus menggunakan gamelan asli yang harganya sangat mahal. Website tersebut juga menyediakan halaman pembelajaran, tata cara menabuh, dan tutorial dalam bentuk video.

Pada awal proyek tersebut, e-gamelan dirancang dengan sistem multi user, yakni setiap alat musik direpresentasikan dengan sebuah laptop. Jika terdapat 11 macam alat musik gamelan maka dibutuhkan 11 laptop untuk memainkannya secara bersamaan. Setiap laptop tersambung saling terhubung yang selanjutnya output dari masing-masing laptop keluar dan menuju perangkat sound system. Cara memainkannya adalah dengan melakukan klik pada perangkat gamelan yang muncul di layar monitor masing-masing laptop. Aransemen suara gamelan diambil dari gamelan asli yang selanjutnya dijadikan standar untuk melakukan tuning output suara gamelan digital. Gamelan asli yang dijadikan sumber aransemen, di antaranya gamelan Keraton Kasunanan Surakarta dan Gamelan Telogo Muncar Keraton Pakualaman Yogyakarta. Pada perkembangan selanjutnya, untuk memperluas diseminasi karya tersebut maka dibuatlah website egamelan.com yang bisa digunakan oleh masyarakat luas untuk belajar gamelan. 


\section{F. Digitalisasi Gamelan di Perangkat Mobile}

Perkembangan teknologi saat ini yang sedang menjadi trend salah satunya adalah teknologi mobile. Beberapa perangkat mobile yang saat ini banyak digunakan oleh masyarakat adalah smart phone, tablet, podcast, dan lain-lain. perangkat tersebut menyediakan banyak fungsi tambahan selain hanya untuk telepon dan sms. Beberapa fungsi tambahan di antaranya kamera, video, televisi, radio, organizer, ${ }^{1}$ game, internet, dan lain-lain. Fungsi tambahan tersebut sering dikenal dengan istilah multimedia.

Selain fungsi-fungsi di atas, perangkat mobile juga masih bisa ditambahi dengan banyak program aplikasi untuk berbagai keperluan, mulai dari entertainment, tools, personalization, permainan, pendidikan, travel, musik, bisnis, olahraga, dan lain-lain. ${ }^{2}$ Kategori pendidikan menempati peringkat 6 dari keseluruhan kategori aplikasi, selain itu aplikasi musik posisi 9 (AppBrain, 2012). ${ }^{3}$

Dari banyak aplikasi tersebut terdapat beberapa aplikasi gamelan digital yaitu Gamelan DJ, Gamelan, Virtual Javanese Gamelan, Gatoel (Gamelan Toetoel), dan Nusa Bahana (AppBrain, 2012). Semua aplikasi tersebut dapat digunakan sebagai sarana untuk belajar gamelan secara mandiri. Yang menarik dari aplikasi tersebut adalah pengguna dapat mengunduh aplikasi secara gratis dan menggunakannya tanpa dipungut biaya sedikitpun. Selain itu, ada aplikasi gamelan yang dapat di-install pada perangkat berbasis sistem operasi Windows Phone ${ }^{4}$ dan iOS. 5 Di WindowsPhone terdapat aplikasi PlayMe Gamelan, sedangkan untuk perangkat berbasis iOS dapat diinstall aplikasi Gamelan Pusaka Pakualam. ${ }^{6}$ Semua aplikasi gamelan gratis, kecuali Gamelan Pusaka

\footnotetext{
${ }^{1}$ Aplikasi untuk mengelola jadwal kegiatan harian seseorang, membuat appointment, membuat event kegiatan dan lain-lain. Organizer ini bersifat seperti asisten pribadi yang akan mengingatkan jadwal kegiatan sewaktu-waktu.

${ }^{2}$ Kategori-kategori tersebut diambil dari perangkat berbasis Android. Namun, kategori yang sama juga berlaku di beberapa sistem operasi yang lain seperti WindowsPhone dari Microsoft, Blackberry dari RIM, dan iOS dari Apple.

${ }^{3}$ Daftar kategori dan peringkat selengkapnya dapat dilihat di http://www.appbrain.com/ stats/android-market-app-categories

${ }^{4}$ WindowsPhone merupakan sistem operasi untuk smartphone yang dikeluarkan oleh produsen software Microsoft Corporation.

${ }^{5}$ Sistem operasi iOS yang dikeluarkan oleh Apple ini hanya terdapat di perangkat-perangkat gadget yang dikeluarkan oleh Apple.

${ }^{6}$ Dikembangkan oleh Tim dari Universitas Dian Nuswantoro Semarang bersamaan dengan proyek e-gamelan berbasis online yang dapat dimainkan di komputer dengan mengakses alamat www.egamelanku.com.
} 
Pakualam yang dikenakan tarif jika ingin mengunduhnya, walaupun harganya juga sebenarnya tidak terlalu mahal untuk sebuah perangkat digital.

Selain aplikasi yang dapat di-install di perangkat mobile, gamelan juga dijadikan sebagai objek penelitian sains yang utamanya adalah mempelajari tentang bunyi gamelan dan mentransfernya ke dalam bentuk digital. Seperti yang dilakukan oleh Scheimer dan Havryliv yang melakukan penelitian mengenai pocket gamelan. Mereka meneliti bagaimana gamelan dapat dimainkan di handphone namun dengan cara melakukan tuning lintasan. Teknologi koneksi yang digunakan untuk menghubungkan antar-handphone adalah bluetooth dan program yang digunakan untuk membangun sistem menggunakan J2ME (Java to Mobile Environment). ${ }^{7}$ Dari hasil penelitian tersebut dapat disimpulkan bahwa teknologi bluetooth dapat diandalkan untuk melakukan pertunjukan gamelan menggunakan handphone secara bersama-sama.

\section{G. Simpulan}

Digitalisasi gamelan adalah salah satu jawaban bahwa instumen musik Jawa terus dikembangkan dalam menjawab tantangan zaman yang semakin modern dan dikepung oleh serbuan teknologi. Gamelan yang memiliki identitas budaya Jawa penuh dengan nilai-nilai Islami dengan berbagai variasi yang diciptakan oleh Sunan Kalijaga. Digitalisasi gamelan ini tidak menyalahi hukumhukum yang berlaku di agama Islam karena hukum yang mengharamkan dengan jelas keberadaan musik tidak ditemukan, baik dalam al-Qur' an dan Hadis. Digitalisasi gamelan dilakukan dengan e-gamelan stand alone, egamelan berbasis internet, dan e-gamelan di perangkat mobile.

\section{Daftar Pustaka}

Adnyana, I. P. 2012. Pengembangan Aplikasi Pembuatan Motif Batik dengan Menggunakan Pengolahan Citra Digital. Karmapati, 1 (2), 249-262.

AGI. 1981. AGI Index. Retrieved Oktober 13, 2012, from American Gamelan Institute Website: http://www.gamelan.org.

Anonim. 2012. Digital. Retrieved Oktober 13, 2012, from Wikipedia Website: http://id.wikipedia.org/wiki/Digital

\footnotetext{
${ }^{7}$ J2ME merupakan teknologi Java yang digunakan untuk membangun aplikasi-aplikasi perangkat mobile terutama wireless di antaranya PDA, communicator, embedded device, smart card, dan ponsel.
} 
AppBrain. 2012. Retrieved 12 29, 2012, from http:/www.appbrain.com/ search?q=gamelan

2012. Andoid Market App Categories. Retrieved 12 29, 2012, from Android Statistics: http://www.appbrain.com/stats/android-marketapp-categories

Chodjim, A. 2003. Mistik dan Makrifat Sunan Kalijaga. Jakarta: Serambi Ilmu Semesta.

Geertz, C. 1976. The Religion of Java. Chicago: University of Chicago Press. Hartana, S. 2006. Notes, Concerns, and Hopes about Javanese Gamelan. Arts, Popular Culture and Social Change in The New Indonesia (pp. 154160). British Columbia, Canada: Centre for Southeast Asia Research University of British Columbia.

Johnson, H. 2008. Composing Asia in New Zealand: Gamelan and Creativity. New Zealand Journal of Asian Studies, 10 (1), 54-84.

KBBI, T. P. 2000. Kamus Besar Bahasa Indonesia. Jakarta: Balai Pustaka.

Latief, M. N., Gaol, F. L., \& Iswanto, B. H. 2010. Analysis and Identification Gamelan Bonang Sound Spectrum. Second International Conference on Computational Intelligence, Modelling and Simulation (pp. 335-338). Bali, Indonesia: IEEE Computer Society.

Mohn, R., Chivers, R., Hatch, M., Howard, S., \& Sachse, W. 1998. Spectrum Analysis of Components of a Central Javanese Gamelan. Accoustic Letters, 1-10.

Muhaya, A. 2003. Bersufi Melalui Musik. Yogyakarta: Gama Media.

Aris Tjahyanto, Yoyon K. Suprapto, Diah Puspito Wulandari. Model Analisisby-Sintesis Aplikasi Pembangkit Suara Gamelan Sintetik, SNATI (Seminar Nasional Teknologi Informasi) 2011, Yogyakarta, Juni 2011.

Y. Tyas Catur P., Fikri Budiman, Sunardi. Desain Virtual Gamelan Jawa Sebagai Media Pembelajaran, SNATI 2010, Yogyakarta, Juni 2010.

Nagashima, Y. 2007. GHI Project and "Cyber Kendang". Conference on New Interfaces for Musical Expression (pp. 250-253). New York: League of Electronic Musical Urban Robots.

Schiemer, G., \& Havryliv, M. 2005. Pocket Gamelan: a Pure Data interface for mobile phones. International Conference on New Interfaces for Musical Expression (pp. 156-159). Vancouver, Canada: Association for Computing and Machinary.

Schiemer, G., \& Havryliv, M. 2006. Pocket Gamelan: tuneable trajectories for flying sources in Mandala 3 and Mandala 4. International Conference 
on New Interfaces for Musical Expression (pp. 37-42). Paris: Association for Computing and Machinary.

Sumarsam. 1992. Gamelan: Cultural Interaction and Musical Development in Central Java. Chicago: The University of Chicago Press.

Walton, S. P. 2007. Aesthetic and Spiritual Correlations in Javanese Gamelan Music.

Wikipedia. 2012. Gamelan. Retrieved 12 28, 2012, from Wikipedia: http:// id.wikipedia.org/wiki/Gamelan. 